\title{
RAD23B wt Allele
}

National Cancer Institute

\section{Source}

National Cancer Institute. RAD23B wt Allele. NCI Thesaurus. Code C104240.

Human RAD23B wild-type allele is located in the vicinity of 9q31.2 and is approximately 49

$\mathrm{kb}$ in length. This allele, which encodes UV excision repair protein RAD23 homolog B protein, plays a role in the repair of DNA damage. 